\title{
PENGEMBANGAN BAHAN AJAR BERBANTUAN GEOGEBRA BERDASARKAN KEMAMPUAN PENALARAN MATEMATIS SISWA
}

\author{
Kathrin Nur Wulandari ${ }^{1}$, Aji Raditya ${ }^{2}$, Barra Purnama Praja ${ }^{3}$ \\ FKIP Universitas Muhammadiyah Tangerang ${ }^{1,2,3}$ \\ aji.raditya21@gmail.com
}

\begin{abstract}
Abstrak
Penelitian ini bertujuan mengkonstruksi bahan ajar (berupa LKS dan applet) berbantuan Geogebra berdasarkan kemampuan penalaran pada materi persamaan lingkaran. Metode penelitian ini adalah tahapan 4-D yang dimodifikasi yaitu pendefinisian, perancangan, dan pengembangan. Hasil penelitian menunjukkan bahwa LKS dan applet yang dikonstruksi berdasarkan penilaian para ahli materi mendapatkan rata-rata skor 4,75 (kriteria sangat baik), ahli media mendapatkan ratarata skor 4,39 (kriteria sangat baik) dan dari ahli media Geogebra mendapatkan ratarata skor 4,59 (kriteria sangat baik). Kualitas kepraktisan LKS dan applet berdasarkan ahli pendidikan mendapat rata-rata skor 4,17 (kriteria sangat baik) dan angket siswa diperoleh rata-rata skor 2,89 dari skor maksimal 4 yang menunjukkan bahwa LKS dan applet yang dikembangkan memiliki kualitas praktis dengan kriteria baik.

Kata Kunci: Pengembangan Bahan Ajar, Geogebra, Persamaan Lingkaran, Penalaran Matematis
\end{abstract}

\begin{abstract}
Aim of this article is to develop Geogebra-assisted teaching materials based on reasoning skills in the material of the circle equation. Teaching materials developed in the form of Student Worksheets (LKS) and GeoGebra applets. The research method used $4 D$ models that have modified. They are defined, designed, and developed. The result of this research showed that teaching materials "very good" based on content expert judgment got an average score of 4,75 from maximum score 5 with outstanding criteria. Based on media expert judgment got an average score 4,39 from maximum score 5 with outstanding criteria and based on Geogebra expert got an average score 4,59 from maximum score 5 with outstanding criteria. The quality of practical teaching materials based on education expert got an average score 4,17 from maximum score 5 with proper criteria and students' response from questionnaires obtained a score 2.89 from a maximum score of 4 which shows teaching materials from the development results have practice quality with proper criteria.

Keywords: Developing teaching material, Geogebra, Circle equation, Mathematical reasoning
\end{abstract}

\section{PENDAHULUAN}

Matematika adalah ilmu yang mempengaruhi perkembangan teknologi serta memiliki peran sangat penting dalam berbagai disiplin ilmu lainnya. Dalam kegiatan belajar-mengajar di Indonesia, matematika merupakan salah satu dari sedikit ilmu yang dipelajari oleh siswa pada setiap jenjangnya. Diharapkan saat siswa menguasai kemampuan berpikir secara matematis, siswa sudah siap menghadapi persaingan global yang kompetitif [1]. Salah satu kemampuan matematis yakni kemampuan dalam membangun konsep dan memecahkan masalah dalam kehidupan sehari-hari.

Penalaran sebagai salah satu kemampuan dasar matematis memiliki hubungan yang sangat erat dengan matematika. NCTM [2] menyatakan bahwa 
terdapat lima kemampuan dasar matematis yang perlu dimiliki oleh para siswa dalam melakukan kegiatan pembelajaran matematik, yakni: pemecahan masalah (problem solving), penalaran dan pembuktian (reasoning and proof), koneksi (connection), komunikasi (communication) dan representasi (representation). Shadiq [3] dan Sobur [4] mengungkapkan bahwa penalaran merupakan proses berpikir untuk menarik suatu pernyataan dan mencapai kesimpulan (atau pengetahuan baru) berdasarkan berbagai pernyataan atau pemikiran yang sebelumnya telah dibuktikan kebenarannya, pengamatan empiris ataupun logika formal.

Kemampuan melakukan pernalaran seringkali digunakan sehari-hari seperti menyusun pola atau hubungan antar materi, menganalisis data, memberi penjelasan sesuai fakta, menyusun kesimpulan yang logis, menyusun serta menguji konjektur (dugaan). Suryadi dalam Hanisa [1] mengatakan kemampuan penalaran pada pembelajaran matematika sangat penting karena pembelajaran lebih ditekankan pada aktivitas berenalaran dan pemecahan masalah. Wahyudin [5] salah satu tanda dari matematika adalah banyaknya permasalahan yang diselesaikan menggunakan penalaran. Siregar [6] mengungkapkan bahwa siswa sangat kurang dalam menyusun bukti, melakukan manipulasi dan menarik kesimpulan. Sehingga siswa cenderung menjawab pertanyaan tanpa mengajukan dugaan terlebih dahulu. Salah satu indikator kemampuan penalaran adalah generalisasi. Generalisasi sangat dibutuhkan dalam belajar matematika untuk melatih siswa dalam membuat kesimpulan melalui pengamatan fakta-fakta yang siswa dapatkan dari pengalaman belajarnya.

Sumarmo [7] dan Lestari [8] mengungkapkan bahwa generalisasi merupakan penarikan suatu kesimpulan yang lebih bersifat umum (yang dapat pula berupa simbol, pola, struktur, data atau gambar) berdasarkan sejumlah data, fakta atau premis yang berupa proposisi empirik. Saat melakukan kegiatan penarikan kesimpulan siswa akan terbantu dengan konjektur yang dibangun berdasarkan pengamatan dari fakta yang ada. Lestari [8] mengungkapkan bahwa indikator kemampuan generalisasi matematika adalah (1) mengenal aturan atau pola, (2) menguraikan aturan atau pola baik secara numerik ataupun secara verbal, (3) menghasilkan aturan umum atau pola umum, (4) menerapkan aturan atau pola dari berbagai persoalan atau kasus khusus dan (5) memformulasikan aturan atau pola tersebut secara simbolik.

SMA Negeri $24 \mathrm{Kab}$. Tangerang adalah salah satu SMA yang berada di Kabupaten Tangerang. Berdasarkan wawancara yang dilakukan pada guru matematika, menyatakan bahwa siswa kesulitan melakukan penalaran dalam pembelajaran matematika khususnya pada materi geometri. Selain itu, siswa juga kesulitan dalam memvisualisasikan pembelajaran geometri hal ini disebabkan oleh gambar kurang presisi karena menggunakan alat tradisional (penggaris, spidol dan jangka). Siswa memerlukan bentuk konkrit dan pengaplikasian materi matematika dalam kehidupannya sehingga siswa dapat memahami materi yang disampaikan oleh guru. Salah satu inovasi dan kreasi guru dalam proses pembelajaran adalah dengan mengkonstruksi bahan ajar yang menarik, inovatif dan interaktif. Sehingga guru dapat menumbuhkan minat dan motivasi para siswa dalam pembelajaran.

Berdasarkan Prastowo [9], bahan ajar adalah kumpulan bahan yang disusun dengan sistematis untuk menampilkan kompetensi yang dipelajari oleh siswa dan selanjutnya digunakan dalam kegiatan belajar-mengajar. Penyusunan bahan ajar 
yang inovatif, kontekstual, variatif, menarik serta sesuai dengan kebutuhan siswa diharapkan dapat menjadikan suasana pembelajaran menjadi lebih menyenangkan, menarik dan berkesan untuk siswa. Salah satu jenis bahan ajar yang digunakan dalam menunjang proses belajar-mengajar adalah Lembar Kerja Siswa (LKS). LKS diharapkan dapat memudahkan guru pada saat menyampaikan materi pelajaran sehingga efisiensi waktu pelaksanaan pembelajaran dapat tercapai. Tujuan pembuatan LKS bermacam-macam, yaitu (1) membantu siswa menemukan atau membangun konsep tertentu, (2) membantu siswa menerapkan dan mengintegritaskan berbagai konsep yang dibangun, (3) penguatan, (4) penuntun belajar, dan (5) petunjuk praktikum. Bagi siswa LKS diharapkan dapat memudahkan interaksi (antara siswa dan materi pelajaran) dan melatih kemandirian belajar. Penggunaan media pembelajaran mendukung penggunaan LKS di kelas sehingga memudahkan siswa dalam memperoleh informasi mengenai materi yang sedang dipelajarinya.

Media pembelajaran merupakan berbagai alat yang digunakan untuk menyampaikan pesan atau materi pelajaran sehingga dapat merangsang perhatian, minat, pikiran dan perasaan siswa dalam kegiatan belajar-mengajar untuk mencapai tujuan. Penggunaan media dalam proses belajar-mengajar membantu siswa dalam menafsirkan berbagai konsep yang abstrak dan menyamakan persepsi. Selain itu, pembelajaran menjadi lebih interaktif dan menarik sehingga meningkatkan minat belajar siswa dan memungkinkan siswa belajar secara mandiri. Dengan demikian proses pembelajaran beralih menjadi student centered atau berpusat pada siswa. Media pembelajaran dalam bentuk komputer dapat membantu guru dan siswa dalam kegiatan belajar-mengajar. Selain itu komputer juga dapat memperjelas dan memudahkan penyampaian pesan kepada siswa [10], serta dapat menyajikan suatu benda atau suatu peristiwa yang terlalu besar, terlalu kecil, tidak tampak di mata, jauh, rumit, bahkan yang kompleks dan berlangsung sangat cepat atau sangat lambat [11]. Salah satu software komputer yang dapat digunakan dalam aktivitas belajar-mengajar matematika adalah GeoGebra.

GeoGebra adalah software yang digunakan untuk mempelajari geometri, aljabar dan materi matematika lainnya yang tidak hanya pada tingkat sekolah menengah melainkan juga pada tingkat perguruan tinggi [12]. Wulandari \& Raditya [13], Syahbana [14] dan Diskovic [12] mengungkapkan bahwa penggunaan Geogebra dapat (1) menghasilkan lukisan-lukisan geometri dengan cepat, tepat dan teliti bahkan lukisan geometri yang rumit, (2) dapat menampilkan animasi atau gerakan manipulasi pada sebuah objek, (3) sebagai bahan evaluasi untuk memvalidasi lukisan geometri yang dikonstruksi siswa, (4) mempermudah untuk menyelidiki sifat-sifat yang berlaku pada suatu objek geometri (5) membantu projek siswa, pemahaman dan pengalaman matematis dalam aktivitas belajarmengajar matematika yang berbasis penemuan, (6) membantu meningkatkan pemahaman matematik siswa, dan (7) dapat menstimulasi guru untuk menggunakan dan mengembangkan visualisasi matematis, penelitian matematika, kelas interaktif matematis di dalam kelas. Sehingga memungkinkan bagi siswa dalam memperluas kemampuan untuk memformulasikan dan membuat dugaan, membuktikan, mengkonstruksikkan, dan mengkomunikasikan argumen yang tepat secara matematis.

Pengembangan LKS berbantuan GeoGebra merupakan bahan ajar cetak berupa LKS berbantuan aplikasi (disebut dengan applet) sebagai media untuk 
memvisualisasi dan mengkonstruksi konsep serta mengkonfirmasi jawaban yang terdapat pada LKS. LKS bertujuan membantu siswa mengembangkan kemampuan yang dibutuhkan dalam mencapai keberhasilan dalam aktivitas belajar-mengajar maupun kehidupan sehari-hari khususnya pada kemampuan generalisasi matematis pada materi geometri

\section{METODE}

Tipe penelitian yang dilakukan adalah penelitian pengembangan. Tujuan dari penelitian ini adalah untuk mengkonstruksi bahan ajar matematika berbantuan Geogebra berdasarkan indikator penalaran yaitu generalisasi. Subjek penelitian adalah siswa SMA Negeri 24 Kabupaten Tangerang pada tahun akademik 2018/2019 sebanyak 30 orang. Model penelitian pengembangan adalah modifikasi dari 4-D models dikembangkan oleh Thiagarajan. Modifikasi yang dilakukan peneliti adalah dengan menyederhanakan tahapan dari awalnya empat tahapan menjadi tiga tahapan, yakni: define, design, dan develop.

Pada tahap define kegiatan yang dilakukan antara lain: menetapkan dan menentukan syarat pengembangan LKS dan applet untuk persamaan lingkaran serta menetapkan tujuan atau kendala untuk LKS dan applet melalui analisis kebutuhan. Tahap design bertujuan untuk menyiapkan suatu rancangan perangkat yang dikembangkan. Pada tahap ini akan dihasilkan rancangan awal berupa Draft I. Pada tahap develop produk yang dikembangkan akan dikaji untuk mengetahui kelayakan dan kepraktisan dari produk tersebut. Draft I yang merupakan hasil dari tahap design akan divalidasi oleh para ahli agar LKS dan applet yang dikembangkan memenuhi kriteria layak dan praktis sehingga akan menghasilkan Draft II. Selanjutnya terhadap Draft II, akan dilakukan uji coba untuk memperoleh respon dari siswa untuk dikaji kepraktisannya. Hasil uji coba akan dijadikan dasar untuk penyempurnaan produk, sehingga produk akhir yang dihasilkan berkualitas.

Jenis data yang terdapat penelitian ini adalah data berbentuk kualitatif dan kuantitatif. Data kuantitatif diperoleh berdasarkan validasi produk oleh para ahli dan para siswa terhadap LKS dan applet yang dikembangkan. Data kualitatif diperoleh dengan mengkonversikan hasil data kuantitatif tersebut. Kualitas LKS dan applet yang dihasilkan diukur berdasarkan validitas dan kepraktisan dari bahan ajar tesebut. Validitas LKS dan applet dilakukan oleh ahli materi, media dan GeoGebra. Kepraktisan LKS dan applet dinilai oleh ahli pendidikan yaitu dosen, guru serta siswa sebagai pengguna produk tersebut. Penilaian kualitas LKS dan applet oleh para ahli digunakan skala Likert (dengan skor maksimal 5). Pada Tabel 1 akan disajikan konversi data kuantitatif ke data kualitatif untuk penilaian ahli.

TABEL 1. Konversi Data

\begin{tabular}{cc}
\hline Interval & Kriteria \\
\hline $\bar{x}>\bar{X}_{i}+1,8 S b_{i}$ & Sangat Baik \\
\hline $\bar{X}_{i}+0,6 S b_{i}<\bar{x} \leq \bar{X}_{i}+1,8 S b_{i}$ & Baik \\
\hline $\bar{X}_{i}-0,6 S b_{i}<\bar{x} \leq \bar{X}_{i}+0,6 S b$ & Cukup \\
\hline $\bar{X}_{i}-1,8 S b_{i}<\bar{x} \leq \bar{X}_{i}-0,6 S b_{i}$ & Kurang \\
\hline $\bar{x} \leq \bar{X}_{i}-1,8 S b_{i}$ & Sangat kurang \\
\hline
\end{tabular}

(Diadaptasi dari Widoyoko, 2009, 238)

Keterangan :

$\bar{x} \quad$ : rerata skor

$\bar{X}_{l} \quad:$ rata-rata ideal $=\frac{1}{2} \times($ skor maksimal ideal - skor minimal ideal $)$ 
$S b_{i} \quad:$ Simpangan baku ideal $=\frac{1}{6} \times($ skor maksimal ideal - skor minimal ideal $)$

Penilaian respon siswa terhadap bahan ajar melalui angket dengan menggunakan skala Likert (dengan skor maksimal 4). Pada Tabel 2 akan disajikan konversi data kuantitatif ke data kualitatif untuk respon siswa. Bahan ajar yang telah dikembangkan dikatakan valid dan praktis jika penilaian yang dihasilkan memperoleh kriteria baik.

$$
\text { Interval }=\frac{\text { skor tertinggi }- \text { skor terendah }}{\text { Jumlah kelas interval }}=\frac{4-1}{4}=0,75
$$

TABEL 2. Konversi Data Kuantitatif ke Kualitatif

\begin{tabular}{cl}
\hline Interval & Kriteria \\
\hline $3,25<\overline{\boldsymbol{x}} \leq 4,0$ & Sangat Baik \\
\hline $2,5<\overline{\boldsymbol{x}} \leq 3,25$ & Baik \\
\hline $1,75<\overline{\boldsymbol{x}} \leq 2,5$ & Kurang \\
\hline $1,0<\overline{\boldsymbol{x}} \leq 1,75$ & Sangat kurang \\
\hline
\end{tabular}

\section{HASIL DAN PEMBAHASAN}

Hasil penelitian adalah LKS dan applet yang dikembangkan berdasarkan kemampuan penalaran dengan menggunakan metode 4-D Thiagarajan [15] yang dimodifikasi sehingga menjadi 3-D.

Pada tahap define dilakukan analisis kebutuhan, tugas konsep dan tujuan pembelajaran. Sehingga diperoleh hasil dengan menganalisis kompetensi inti serta kebutuhan siswa. Pengembangan LKS dan applet ini berdasarkan kemampuan penalaran khususnya pada kemampuan generalisasi. Tahap design berisi perencanaan peneliti dalam mengkonstruksi bahan ajar berdasarkan indikator kemampuan generalisasi siswa yang berbentuk LKS dan applet Geogebra dengan ekstensi .ggb. Produk yang dihasilkan dinamakan Draft I. Pada tahap develop, draft I hasil pengembangan pada tahap design dinilai kevalidan dan keraktisannya. Draft I dinilai kevalidannya oleh 3 ahli yaitu (1) ahli materi, (2) ahli media, dan (3) ahli media. Berdasarkan hasil validasi oleh 3 ahli tersebut diperoleh :

TABEL 3. Penilaian Ahli Materi

\begin{tabular}{clcl}
\hline NO & Aspek & Rata-rata & Kriteria \\
\hline 1 & Kelayakan isi & 4,479 & Sangat Baik \\
\hline 2 & Kebahasaan & 5 & Sangat Baik \\
\hline 3 & Penyajian & 5 & Sangat Baik \\
\hline & Total & $\mathbf{4 , 7 5}$ & Sangat Baik \\
\hline
\end{tabular}

TABEL 4. Penilaian Ahli Media

\begin{tabular}{clcl}
\hline NO & Aspek & Rata-rata & Kriteria \\
\hline 1 & Kebahasaan & 4,333 & Sangat Baik \\
\hline 2 & Penyajian & 4,667 & Sangat Baik \\
\hline 3 & Kegrafikan & 4,333 & Sangat Baik \\
\hline & Total & $\mathbf{4 , 3 8 9}$ & Sangat Baik \\
\hline
\end{tabular}


TABEL 5. Penilaian Ahli Media Geogebra

\begin{tabular}{cccl}
\hline NO & Aspek & Rata-rata & Kriteria \\
\hline 1 & Pemograman & 4,4 & Sangat Baik \\
\hline 2 & Desain grafis & 4,833 & Sangat Baik \\
\hline 3 & Kegrafikan & 4,5 & Sangat Baik \\
\hline & Total & $\mathbf{4 , 5 8 8}$ & Sangat Baik \\
\hline
\end{tabular}

Secara umum hasil penilaian terhadap bahan ajar berupa LKS dan applet adalah "layak digunakan dengan revisi" dan hasil perhitungan dari validator memperoleh hasil "Sangat Baik". Setelah melakukan validasi, produk yang dikonstruksi direvisi untuk selanjutnya dilakukan uji coba. Produk tersebut diberi nama Draft II.

Penilaian kepraktisan produk dilakukan oleh dua ahli pendidikan serta dilakukan uji coba kepada 30 siswa untuk memperoleh respon siswa setelah menggunakan produk tersebut. Berdasarkan hasil penilaian diperoleh :

TABEL 6. Penilaian Ahli Pendidikan

\begin{tabular}{llcl}
\hline NO & \multicolumn{1}{c}{ Aspek } & Rata-rata & \multicolumn{1}{c}{ Kriteria } \\
\hline 1 & Kelayakan isi & 3,937 & Baik \\
\hline 2 & Kebahasaan & 4,25 & Sangat Baik \\
\hline 3 & Penyajian & 4,167 & Baik \\
\hline 4 & Kegrafikan & 4,214 & Sangat Baik \\
\hline 5 & Pemograman & 4,333 & Sangat Baik \\
\hline & Total & $\mathbf{4 , 1 6 7}$ & Baik
\end{tabular}

TABEL 7. Penilaian Angket Respon Siswa

\begin{tabular}{clcl}
\hline NO & Aspek & Rata-rata & Kriteria \\
\hline 1 & Kebahasaan & 3,058 & Baik \\
\hline 2 & Penyajian & 3,083 & Baik \\
\hline 3 & Kondisi & 2,834 & Baik \\
\hline & Total & $\mathbf{2 , 8 9}$ & Baik \\
\hline
\end{tabular}

Berdasarkan hasil penilaian kepraktisan terhadap LKS dan applet yang dikembangkan diperoleh "praktis" dengan kriteria "baik". Melalui kegiatan uji coba yang dilakukan, diperoleh bahwa siswa sangat tertarik dan senang belajar menggunakan produk ini. Sehingga minat serta motivasi terhadap pembelajaran menggunakan produk ini sangat tinggi. Penggunaan LKS dan applet ini membantu siswa memvisualisasikan gambar yang dibentuk oleh persamaan lingkaran dengan akurat dan jelas serta siswa lebih mudah mengeneralisasi setiap perubahan yang terbentuk pada persamaan lingkaran. 


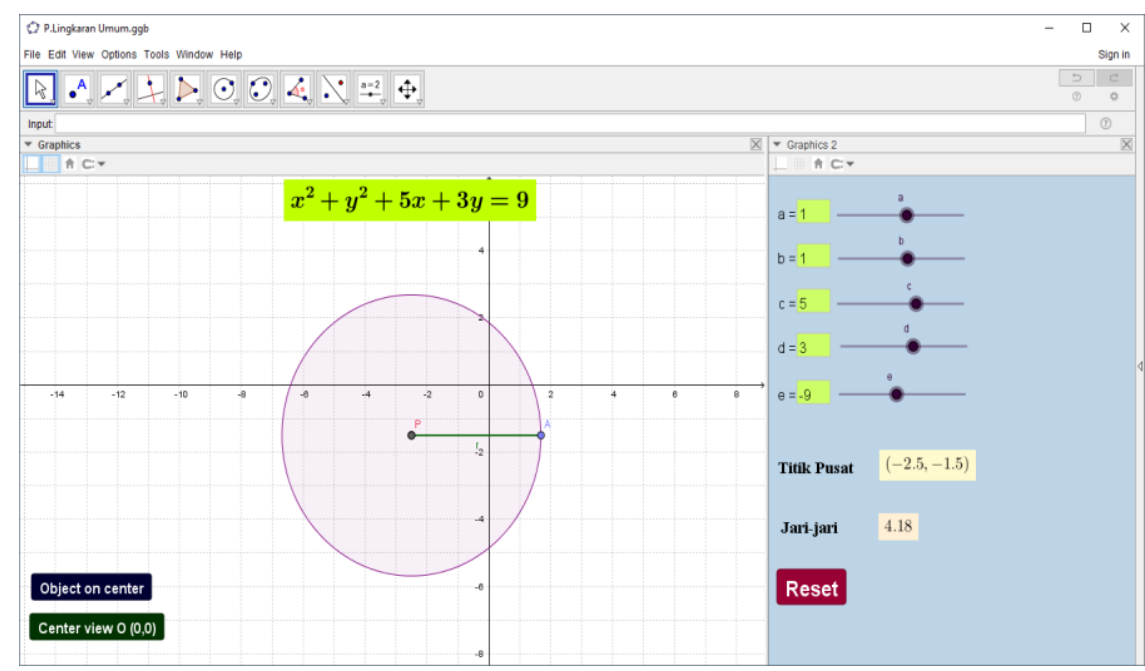

GAMBAR 1. Tampilan applet Geogebra

\section{KESIMPULAN}

Hasil dari validator terhadap LKS dan applet yang dikembangkan adalah "sangat baik". Berdasarkan penilaian dari pengguna LKS dan applet ini, yaitu ahli pendidikan yang merupakan dosen dan guru serta siswa, dapat dikatakan bahwa LKS dan applet yang dikembangkan masuk kriteria "praktis". Hasil lainnya diperoleh melalui observasi ketika kegiatan belajar-mengajar berlangsung adalah penggunaan LKS dan applet ini dapat menumbuhkan minat, motivasi serta membantu visualisasi siswa saat mempelajari geometri.

\section{DAFTAR RUJUKAN}

[1] Hanisa. (2010). Pembelajaran Matematika dengan Model Core melalui Pendekatan Keterampilan Metakognitif untuk Meningkatkan Kemampuan Penalaran Matematis Siswa Sekolah Menengah Pertama. Bandung: Tesis Universitas Pendidikan Indonesia.

[2] NCTM. (2000). Principles and Standards for School Mathematics. United State of Amerika: NCTM.

[3] Wardhani, S. (2008). Analisis SI dan SKL Mata Pelajaran Matematika SMP/MTs untuk Optimalisasi Tujuan Mata Pelajaran Matematika. Yogyakarta: PPPPTK Matematika.

[4] Sobur, H. A. (2015), Logika dan Penalaran dalam Perspektif Ilmu Pengetahuan. TAJDID, XIV.

[5] Wahyudin. (2008). Pembelajaran dan model-model pembelajaran. Bandung: UPI PRESS.

[6] Siregar, N. (2016). Meninjau Kemampuan Penalaran Matematis Siswa SMP meelalui Wawancara Berbasis Tugas Geometri. Jurnal Pendidikan Matematika STKIP Garut.

[7] Sumarmo, U. (2010). Berpikir dan Disposisi Matematik: " Apa, Mengapa, dan Bagaimana dikembangkan pada peserta didik. FMIPA UPI.

[8] Lestari, K. E., \& Yudhanegara, M. R. (2017). Penelitian Pendidikan Matematika (Panduan Praktis Menyusun Skripsi, Tesis, dan Laporan Penelitian) dengan Pendekatan Kuantitatif, Kualitatif, dan Kombinasi Disertai dengan Model Pembelajaran dan Kemampuan Matematika. Bandung: Refika Aditama.

[9] Prastowo, A. (2015). Panduan Kreatif Membuat Bahan Ajar Inovatif: Menciptakan Metodee Pembelajaran yang Menarik dan Menyenangkan. Jogyakarta: Diva Press.

[10] Susilana, R., \& Riyana, C. (2007). Media Pembelajaran. Bandung: Wacana Prima.

[11] Daryanto. (2015). Media Pembelajaran. Bandung: Sarana Tutorial Nurani Sejahtera.

[12] Dikovic, L. (2009). Applications GeoGebra into Teaching Some Topics of Mathematics at the College. ComSIS, 6 No.2. doi:10.2298/csis0902191D 
[13] Wulandari, K. N., \& Raditya, A. (2017). Pengembangan Lembar Kerja Siswa pada Materi Geometri Transformasi Menggunakan Geogebra. Prima: Jurnal Pendidikan Matematika, 8390.

[14] Syahbana, A. (2016). Belajar Menguasai GeoGebra (Program Aplikasi Pembelajaran Matematika). Palembang: NoerFikri Offset.

[15] Thiagarajan, S., Semmel, D. S., \& Semmel, M. I. (1974). Instructional Development for Training Teachers Exceptional Children: A Sourcebook. Minneapolis: Indiana University. 